\title{
A Study to Analyse the Perception of Commuters' towards Service Quality of Delhi Metro Rail Corporation: Empirical Study
}

\author{
Yogendra Pal Bharadwaj ${ }^{1}$, Mukesh Singh ${ }^{2}$ \\ ${ }^{1}$ Assistant Professor, IBM, GLA Un iversity, Mathura (U.P.), India. \\ ${ }^{2}$ Assistant Professor, IBM, GLA University, Mathura (U.P.), India.
}

Article History: Received: 11 January 2021; Accepted: 27 February 2021; Published online: 5 April 2021

\begin{abstract}
In modern era of globalization, the services being offered by the public transportation require to gauge sensitivity about the services offered to the common masses. In this context, this study examined the perception of commuters on service quality offered by Delhi Metro Rail Corporation and its impact on the commuter's satisfaction. Therefore, five dimensions of service quality have been taken (reliability, tangibility, empathy, safety \& security, commuters' friendliness) as predicting variables towards the commuters' satisfaction of DMRC. This research was carried out on behalf of a convenience sampling approach using basic condition and structural equation modelling with an aggregate of 1045 questionnaires distributed among commuters via electronic form as well as simple form. The results of factual tests show that four out of five predictive variables viz., commuters' friendliness, tangibility, safety \& security, empathy have pragmatic percussion, while reliability and commuter's friendliness has no remarkable influence on customer's satisfaction.
\end{abstract}

Keywords: Commuter's Perception, Service Quality, Commuter's Satisfaction.

\section{Introduction}

Service quality is envisaged normally as the cluster of customer's perception of service experience (Wang, K. Y., Hsu, L. C., \& Chih, W. H., 2014). The difference between commuter's satisfaction and service quality is satisfaction is always related to a particular transaction, whereas service quality itself is a global judgement (Zeithaml \& Berry, Parasuraman, Valarie, 1985). Service expectations are normally formed amongst customers based on several sources like the way of advertisement, past experience, the perceived services and their comparison with other service providers. Customers are perceived as mere a consumer of output of service quality; they should be considered as co-producer of service quality process and it has become an influential competitive factor (Hossain, M. J. (2012). Triumphant organization either private or public transportation put in benefits to their offer that not only gratify customers but provide surprise and delight and delight of customer is a matter of exceeding expectations. Service quality is known as an essential realm on which public organizations including transportation services are focusing in present times (Nandan, Shefali, 2010).

Delhi Metro plays a vital role in transportation sector and is executed in much dynamic way in this present scenario. With the view to ensure the safety and reliability of commuters, Delhi metro is equipped with several contemporary technologies which ease the commuters in several ways. Delhi metro strives to provide the pleasure to commuters based on the train's frequency that availability of trains is possible after each three minutes of departure (Ettema, D., Friman, M., Gärling, T., Olsson, L. E., \& Fujii, S., 2012). To meet with the emerging demands of metro prospects' and to avert the jinx of clients it cannot be bewildering that Delhi metro organization has to develop an indispensable interest to uplift the comfort part of their services offerings through an innovative worldview of service quality. Service quality is a point where the performance is measured of the organization along with the business intensions so imbibing the service quality in metro industry should be a great zeal for industry people and researchers too (Yang, M., Zhao, J., Wang, W., Liu, Z., \& Li, Z., 2015).

Here in this research paper, examination would be conducted on service quality dimensions and commuter's satisfaction in Delhi Metro Rail Corporation. The focus is to identify that which service quality dimensions taken would be indispensable for the commuters gratification. This research study will help to explore out the significant factors in Delhi Metro Rail Corporation that have strong influence on commuters' satisfaction and affect the commuters' commuting decision and add them to the sense of belonging and brand loyalty among commuters'. It is also aimed to identify if any relation exists between commuters satisfaction and service quality in DMRC and also to measure the impact of service quality dimensions taken on commuter's satisfaction in Delhi Metro Rail Corporations. The result of this research study can be applicable in Delhi Metro industry to enhance their service quality for uncountable commuter's coming from several corners of the world as service quality is directly is in association with the grand success of any public corporation because if commuter's would be delighted the chance of loyalty and retention also enhances therefore the service quality should be kept at utmost priority.

\section{Background Conceptualization}

At this juncture the comprehensive literature review carried out on dependent variable commuter's satisfaction and predictor variables of service quality. 


\subsection{Commuter's Satisfaction}

Competition is the point where the quality of product and services restructures offering to expand its market among the different commuter's if the organization offers services below the expected level of commuters then organization cannot imagine expand the wing of its business and will lose the loyalty and the retention of the commuters. Commuter's satisfaction can be evaluated as the sensitivity that a commuter experiences, when an offered service meet up to their desired expectations. Beirão, G., \& Cabral, J. S. (2007) have tried to reveal in their research that high level of comfort for both commuters and staff who are all travelling in metro rail should exist. The commuters experience differs from each other's and the service providers should improve the passenger's amenities which will result in commuter's satisfaction.

\subsection{Service Quality}

Service quality has become the buzzword to conduct the research since last many decades. Service quality can be ratiocinated as the way how services are offered to meet the customer's expectations. Perceived quality is developed on the basis of exposures of customers which enhance their experiences of varieties of services being offered in all the corners of world. The level of customers' satisfaction and dissatisfaction absolutely depends upon the perceived services by the customers if their expectation meets to the services being offered they are gratified else they are not (Gallifa \& Batalle, 2010).

Providers of services on equal interval of time use to examine the service quality offered to their customers having an aim to enhance the quality and also to gauge the customers demand to meet in an incomparable way. The fuss of service quality came into picture in the year 1980 when uncountable organizations came to know that quality of any product or service only can let the business remain alive (Santouridis, I., \& Trivellas, P. (2010). Service quality is not lucrative only to get the loyal prospects but also makes the organization a point of profit maximization in this competitive environment (Karim \& Chowdhury, 2014). Many scholars have cited that customer satisfaction is a key to get the customer loyalty and their retention but having no prediction about their future purchases. To measure the customer's perceptions revised SERVQUAL model was utilized. The revised SERVQUAL model of Parasuraman et al. (1988) suggested a five-dimensional model of service quality which includes reliability, tangibility, empathy, safety \& security, commuter's friendliness as a tool to measure the dimension of these determinants on commuters' satisfaction.

\subsubsection{Reliability}

Reliability is the willingness of service providers to meet their expectations in a guaranteed way. In service industry the working staffs are supposed to be on their toes to entertain the customer's queries related to products and services offered (Ojo, 2010). Customers want to be responded immediately as per their expectations. Therefore, countless commutation means are made available to provide the instant response to the queries made by commuters'.

\subsubsection{Tangibility}

Tangibility is the essential factor of service industry, it includes physical manifestation, people involved in providing services including their exterior appearance and all correspondence elements (Parasuraman et al., 1988). If the physical evidences required by the service industries lacks the customers would not be willing to avail the services in future and automatically the customer's relation would be lost (Anjum, U., Aftab, J., Sultan, Q., \& Ahmed, M., 2016).

\subsubsection{Empathy}

Empathy is all about singularizing concentration of a company towards its customers. Empathy defines the level of interaction between customer and the service providers. Gray, B., \& Boshoff, C. (2004) anticipated that to draw the customers attention, caring and service verities are the indispensable elements otherwise the customers in this cut throat competition would go somewhere else in search of their service pleasure (Armstrong, R. W., Mok, C., Go, F. M., \& Chan, A., 1997).

\subsubsection{Safety \& Security}

Safety \& Security represents the skill and courteousness of the employees and their capability to implant confidence in the customers. It includes the factors like privacy, protection, courteousness and knowledge. Privacy refers to behaviour of employees that builds confidence among customers. Security of commuter's denotes the feeling of security in the customer mind during their transactions with employees (Knutson, B., Stevens, P., Wullaert, C., Patton, M., \& Yokoyama, F. (1990). Employee's courteous behaviour with the customers is also a vital factor and knowledge of the employees to answer to customers queries also plays an imperative function. 


\subsubsection{Commuter's Friendliness}

Commuter's friendliness states that an eye-catching and efficient public transport system should provide a level of service to its users in order to switch from private vehicles to public transport (Botzoris et al., 2015; Wu, S., Bai, Q., \& Sengvong, S., 2018). The improvement of service quality can be achieved by a clear understanding of travel behaviour and commuters' needs, their comfort level and expectations (Beirão and Cabral, 2007).

In the light of above background and conceptualization, the theoretical framework of this research was taken from previous researches in the stated objectives, accordingly it has five hypotheses as given below:-

H1: Reliability has positive impact on commuter's satisfaction in Delhi Metro Rail Corporation.

H2: Tangibility has positive impact on commuter's satisfaction in Delhi Metro Rail Corporation.

H3: Empathy has positive impact on commuter's satisfaction in Delhi Metro Rail Corporation.

H4: Safety \& security has positive impact on commuter's satisfaction in Delhi Metro Rail Corporation.

H5: Commuter's friendliness has positive impact on commuter's satisfaction in Delhi Metro Rail Corporation.

Therefore, in the light of above stated hypotheses and objectives of the study, a conceptual model is proposed as under:

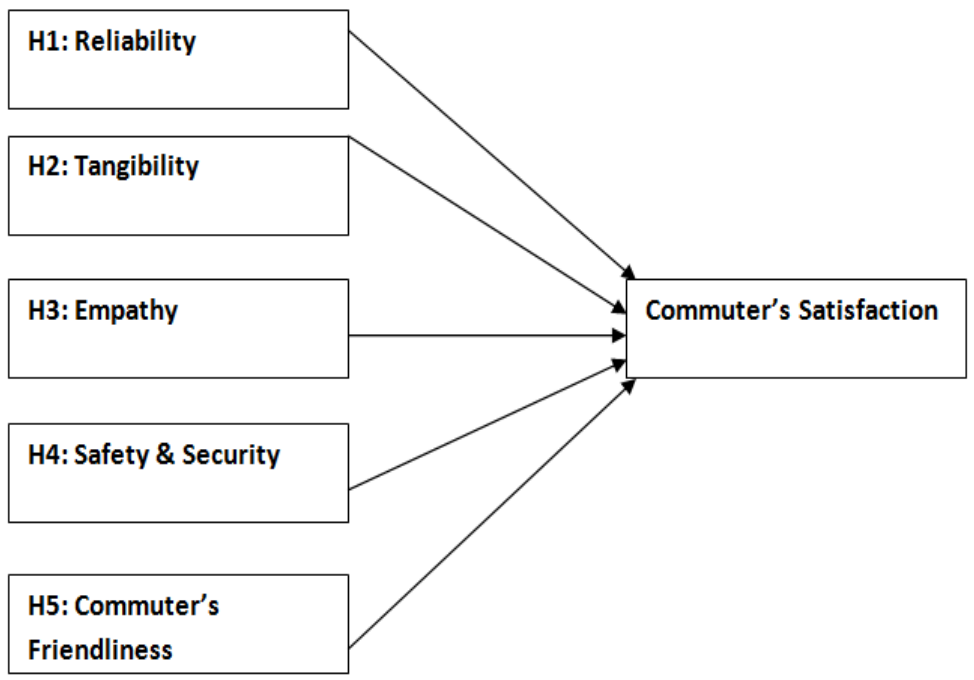

Figure 1: Conceptual Research Model

Source: Prepared by the researchers

\section{Research Design}

Convenience sampling was utilized to collect the required information from commuters of Delhi Metro Rail Corporation and collected data from questionnaires were arranged in such a manner so that the desired information related to the commuter's satisfaction and service quality provided by DMRC. Research focused mainly to examine the variables which could impact the commuter's satisfaction with dimensions taken of service quality. A collection of 1200 questionnaires were given among the commuters' of Delhi Metro Corporation.

This research is dependent on definitive research where the research agents utilized reliability, tangibility, empathy, safety \& security, commuters' friendliness and Commuters' Satisfaction facets to gather data from professionals offering their services in Delhi Metro Rail Corporation. The constituent of 'reliability and tangibility factor' were mustered from the analysis of Hossain, M. J. (2012) and Santouridis, I., \& Trivellas, P. (2010).

However, 'safety \& security factor' were outcome from the studies of Nandan, Shefali (2010) and Botzoris, G., Galanis, A., Profillidis, V., \& Eliou, N. (2015). These investigations undertaken by Wu, S., Bai, Q., \& Sengvong, S. (2018), Yang, M., Zhao, J., Wang, W., Liu, Z., \& Li, Z. (2015), and Gallifa, J., \& Batallé, P. (2010) have recognized in terms of 'empathy \& commuters' friendliness'. While, the studies of Ettema, D., Friman, M., Gärling, T., Olsson, L. E., \& Fujii, S. (2012), Karim, R., \& Chowdhury, T. (2014) and Yang, M., Zhao, J., Wang, W., Liu, Z., \& Li, Z. (2015) have acknowledged for 'commuters' satisfaction'. After we break down information normality, outlier multivariate, and multi-co linearity, researchers gathered information from 1200 practitioners' which can be applied in dislimbing of hypotheses designed based on stated objective (Hooper, D., Coughlan, J., \& Mullen, M. R., 2008).

This exploration study has used descriptive statistics, factor analysis and Structural Equation Modelling (SEM) with SPSS 20.0 and AMOS 20.0. Then again table one explains the estimates of the variables and its 
A Study to Analyse the Perception of Commuters' towards Service Quality of Delhi Metro Rail Corporation: Empirical Study

criticalness for the confirmatory factor analysis of 34 items with basic fundamental components (Bentler P.M., 1990; Byrne, B.M., 2001).

\subsection{Sample Design and Procedure}

Convenience testing technique was used and questionnaire undertaken was based on five-point Likert scale. The fundamental area covered demographic profiles (sex, vacation, metro engagement commitment, age and qualification) of the metro professionals'; while, the resulting portion dealt with the self-sufficient components of different variables undertaken.

The information was gathered in two different stages ranging from December 2019 to February 2020. At preliminary phase, to conduct the pilot study the data of 150 respondents were created and in the subsequent stage, information was made using greater samples of 1200 experts of DMRC, the population comprises of commuters' commuting from DMRC.

As per the reports generated yearly by central record division, the several divisions have good number of metro commuters as per the reports generated by statuary managing bodies (Corry, A., 1997; Bharadwaj, Y.P. \& Singh, M., 2020; DMRC, 2018). Keeping these all in views, 1200 questionnaires were released as past analysis have witnessed an extent of comparative response (Cavana, R., Delahaye, B., \& Sekaran, U., 2000).

Out of 1200, just 1045 respondents responded to the questionnaires as symbolized by rule of thumb technique, the sample size of 1045 restorative specialists' is aggregate (Krejcie and Morgan, 1970). This evinces 87 percent of reaction rate which is high in comparison of response rates betrayed in these sorts of studies conducted by different researchers (Sekaran, U., 2003). The general scale reliability was observed as.892 which is satisfactory (Cronbach, L. J., 1951). Factor credibility was verified in table one and indicators for all loading factor and construct reliability were confirmed above 0.4 and 0.7 (Kerlinger, F.N., 1986).

Table I. Confirmatory Factor Analysis

\begin{tabular}{|c|c|c|c|c|c|}
\hline Construct & Items & Factor Loading & Critical Ratio & $\mathrm{p}$ & $\begin{array}{l}\text { Construct } \\
\text { Reliability }\end{array}$ \\
\hline \multirow{6}{*}{ Reliability } & REL1 & .692 & 5.423 & .000 & \multirow{6}{*}{.882} \\
\hline & REL2 & .594 & 5.412 & .000 & \\
\hline & REL3 & .527 & 6.612 & .000 & \\
\hline & REL4 & .592 & 5.982 & .000 & \\
\hline & REL5 & .581 & 7.243 & .000 & \\
\hline & REL6 & .656 & 5.167 & .000 & \\
\hline \multirow{5}{*}{ Tangibility } & TAN1 & .761 & 5.528 & .000 & \multirow{5}{*}{.829} \\
\hline & TAN2 & .751 & 7.891 & .000 & \\
\hline & TAN3 & .635 & 5.209 & .000 & \\
\hline & TAN4 & .529 & 6.754 & .000 & \\
\hline & TAN5 & .642 & 6.459 & .000 & \\
\hline \multirow{5}{*}{ Empathy } & EMP1 & .671 & 5.987 & .000 & \multirow[t]{5}{*}{.981} \\
\hline & EMP2 & .582 & 6.462 & .000 & \\
\hline & EMP3 & .782 & 7.761 & .000 & \\
\hline & EMP4 & .821 & 5.672 & .000 & \\
\hline & EMP5 & .912 & 7.982 & .000 & \\
\hline \multirow[t]{4}{*}{ Safety \& Security } & SFS1 & .732 & 6.452 & .000 & \multirow[t]{4}{*}{.894} \\
\hline & SFS2 & .756 & 7.981 & .000 & \\
\hline & SFS3 & .798 & 5.452 & .000 & \\
\hline & SFS4 & .834 & 6.781 & .000 & \\
\hline \multirow{7}{*}{ Commuters' Friendliness } & CF1 & .578 & 6.267 & .000 & \multirow{7}{*}{.847} \\
\hline & $\mathrm{CF} 2$ & .654 & 7.341 & .000 & \\
\hline & CF3 & .651 & 7.174 & .000 & \\
\hline & CF4 & .762 & 6.176 & .000 & \\
\hline & CF5 & .798 & 5.983 & .000 & \\
\hline & CF6 & .561 & 6.762 & .000 & \\
\hline & CF7 & .571 & 7.652 & .000 & \\
\hline \multirow{3}{*}{ Commuters' Satisfaction } & CS1 & .594 & 6.892 & .000 & \multirow[b]{3}{*}{.862} \\
\hline & CS1 & .763 & 7.451 & .000 & \\
\hline & CS2 & .742 & 6.971 & .000 & \\
\hline
\end{tabular}


A Study to Analyse the Perception of Commuters' towards Service Quality of Delhi Metro Rail Corporation: Empirical Study

\begin{tabular}{|l|l|l|l|l|l|}
\hline \multirow{4}{*}{} & CS3 & .639 & 6.478 & .000 & \multirow{2}{*}{ CS4 } \\
\cline { 2 - 5 } & CS5 & .629 & 6.735 & .000 \\
\cline { 2 - 5 } & CS5 & .790 & 7.691 & .000 \\
\cline { 2 - 5 } & CS6 & .649 & 6.872 & .000 & \\
\hline
\end{tabular}

Source: Survey data and prepared by the researcher

\section{Data Analysis and Results}

\subsection{Descriptive Analysis of Demographic Factors}

As per metro commuters blueprint reliant on demographic orientation, out of 1045,730 commuters fallen under males category and remaining 315 commuters fallen under obliviously females category. Wherein $15 \%$ of total population were aged in-between 19 to 34 years, 45 years old commuters were $55 \%$ and $30 \%$ were aged inbetween 35-44 years which reveals that most of the expert's are adequately developed to realize the vicinity of hierarchical obligation and the components of their satisfaction through factors of service quality. Regarding vocational expansion of metro commuter's greater number of commuters were from service class say for instance (45\%) and 35 percent commuter's were from business class, 20 percent commuters were from students class, to the extent of student's educational outline it was undergraduate 25 percent, post graduate 40 percent and remaining were from non graduate background. It implies foremost part of specialists' realize the diversified way to handle with their professional commitment criteria wisely. Most definitely, 25 percent commuters' were of over ten years, 40 percent were in-between 5 to 10 years length, 15 percent were in-between 2 to 5 years, and 20 percent were below 2 years that means still experts are sufficiently developed to figure out the worldview approach of their service quality attributes in the metro industry of Delhi Metro Rail Corporation (Churchill, Gilbert A., Jr. and Carol Surprenant. (1982).

\subsection{Hypotheses Testing and Results}

To the degree of hypotheses testing plotted in table two and three, the results exhibited considerable relationship of tangibility on organizational commitment $(p=0.008 ; \beta=.72)$, however, its posits 72 percent estimation impact commuters', while the basic proportion $(\mathrm{CR}=6.796)$ heightens it acts as a significant determinant for metro practitioners' completion, so this hypothesis got accepted (Brown, T. J., Gilbert A. Churchill, Jr., \& Peter, J. P., 1993). On the other hand, empathy estimation $(p=0.151 ; \beta=.48)$ vehemently not affected organizational commitment towards metro commuters' fulfillment made by Delhi Metro Rail Corporation, so this hypothesis got rejected (Churchill, Gilbert A., Jr. and Carol Surprenant, 1982). While, metro commuters' fulfillment ( $p=0.025 ; \beta=.62)$ is strongly affected towards their organizational commitment to yield Delhi Metro Rail Corporation benefits frequently, so this hypothesis is accepted. It furthermore communicated that the metro workers are increasingly concerned over commuters' to generate and hold affection among them. With the view to examine the association between estimations of empathy and tangibility among metro commuters' fulfilment, all determinants were found having significant relationship regarding services delivery offered by Delhi Metro Rail Corporation. Therefore, the examination further demonstrated that empathy variable $(p=0.048 ; \beta=.56)$ and tangibility factor $(p=0.023 ; \beta=.61)$, were key for influencing metro commuters' satisfaction, so these hypotheses also got accepted (Cronin,.J.J., Brady. M.K. and Hult, G.T., 2000).

Table II. Summary of Hypothesis Testing

\begin{tabular}{lllll}
\hline \multicolumn{1}{c}{ Hypotheses } & Estimate & C.R. & P & Result \\
\hline Reliability $\rightarrow$ Commuters' Satisfaction & .584 & 5.872 & 0.181 & Rejected \\
Tangibility $\rightarrow$ Commuters' Satisfaction & .682 & 6.697 & .007 & Accepted \\
Empathy $\rightarrow$ Commuters' Satisfaction & .694 & 5.817 & 0.038 & Accepted \\
$\begin{array}{l}\text { Safety \& Security } \rightarrow \text { Commuters' } \\
\text { Satisfaction }\end{array}$ & .579 & 6.527 & 0.021 & Accepted \\
$\begin{array}{l}\text { Commuters' Friendliness } \rightarrow \text { Commuters' } \\
\text { Satisfaction }\end{array}$ & .695 & 5.961 & 0.015 & Accepted \\
\hline
\end{tabular}

Source: Survey data and prepared by the researcher

Table III. Estimated Model's Test Statistics

\begin{tabular}{lll}
\hline Fit Index & Recommended Values & Observed Values \\
\hline CMIN/DX & $<0.30$ & 271.158 \\
GFI & 0.90 & 0.953 \\
AGFI & 0.80 & 0.859 \\
NFI & 0.90 & 0.945 \\
CFI & 0.90 & 0.963 \\
RMSEA & $<0.70$ & 0.057 \\
\hline
\end{tabular}


Notes: CMIN/D.F - Chi-square value/degrees of freedom, GFI - Goodness of Fit Index, CFI - Comparative Fit Index, NFI - Normated Fit Index, AGFI - Adjusted Goodness of Fit Index, RMSEA - Root Mean Square Error of Approximation.

${ }^{*}$ Sourced from Hair, J.F., Black, W.C., Babin, B.J. \& Anderson, R.E., 2010; Hooper, D., Coughlan, J., \& Mullen, M.R., 2008; Hu, L.-t., \& Bentler, P.M, 1998; Kerlinger, F.N., 1986.

Source: Survey data and prepared by the researcher.

In the process of untying the entire relationship, tangibility $(\beta=.72)$ is an essential determinant of metro commuters' satisfaction, while, organizational commitment $(\beta=.58)$ developed a reasonable strive to have a comparable relationship between metro commuters' fulfilment and attributes of service quality towards Delhi Metro Rail Corporation (Dean A., 1999). However, metro commuters' fulfilment is recognized the most excellent outcome on service quality variable to make constructive vicinity of association between these two factors (Grönroos, C., 2000).

In the context of service quality, the ensuing part of empathy $(\beta=.48)$ has not been much affected in the thought of metro commutation (Khan, Mubbsher Munawar, and Mariam Fasih, 2014). As a result, it displays empathy is not the most influencing element for service quality in Delhi Metro Rail Corporation. Besides as mentioned under table three, RMSEA scores underneath 0.10 are usually seen as of good sign fit, and our value is 0.08, which is a strong counterpart for the model (Bentler P.M, 1990; Byrne, BM, 2001; Cavana, R., Delahaye, B., \& Sekaran, U, 2000). In this regard, it is exhibited that four hypotheses are mainly influencing the association between measurements of service quality like empathy and tangibility on metro commuters' satisfaction that improve the gradual replica of Delhi Metro Rail Corporation through their commitment in the commutation field for better and productive services (Hill, Nigel, and Jim Alexander, 2000; Gao, Yanan, Soora Rasouli, Harry Timmermans, and Yuanqing Wang, 2017).

\section{Discussion and Implications}

This research analysis gauged the relationship amongst determinants of service quality, tangibility, reliability, empathy, safety \& security and commuters' friendliness among the DMRC metro commuter's fulfilment and enquired the influence of these gauging having a sample size of 1045 commuters' on each other in DMRC for whom the designed questionnaires were released formally. The outcome betrayed that commuters' friendliness is identified as prominent aspect among all the estimations for service quality. In addition, metro commuters' fulfilment showed a lucrative impact on commitment with due conception of conduct of an experts' so these parts may not quash their both fulfilment along with commitment concerned with DMRC. In contemplation of commuter satisfaction, commuters' friendliness has been noticed at high priority among all the measurements and tangibility articulated an incomparable impingement on psyches level of metro commuters'. So they may not undervalue towards their work commitment, whereas, metro professionals' fulfillment is concerned; reliability is apparently the least decision factor among the entirety of the measurements in DMRC. These divulgences could act as overtures for DMRC experts to assess their affiliation and its outcomes for metro commuters' so it can represent a valuable result to escalate the metro industry (Chopra, T.J.S. (1994).

Current investigation was carried out to discover the components which affect on commuter's satisfaction in DMRC. Measurements of service quality included within the research were reliability, tangibility, empathy, safety \& security and commuter's friendliness whereas commuter satisfaction was considered as dependent variable. The analysis confirmed that one independent variables i.e. commuters' friendliness had positive influence on commuter's satisfaction while reliability had least influence on commuter's satisfaction whereas tangibility, empathy, safety \& security and commuters' friendliness had positive and significant effect on commuters satisfaction. The results of this research will help the DMRC to improve their service quality which will enhance the customers' satisfaction and loyalty. Hence, it will increase the stake and credibility of the metro industry.

\section{Limitations and Future Research Directions}

This exploration was restricted to examine the relationship of selection of service quality attributes in context to commuters' satisfaction in DMRC. Further appraisal in different sorts of affiliations may give arranged data into the exposures of this assessment. As exhibited by the fundamental of the distinctive business assessments could either be added or revamped to fit the association as required by varying situations and emerging business trends.

Funding: This research did not receive any specific grant from funding agencies in the public, commercial, or not-for-profit sectors.

Conflict of Interest: Not Available.

Ethical Clearance- Not required as per study. 


\section{References}

1. Anjum, U., Aftab, J., Sultan, Q., \& Ahmed, M. (2016). Factors affecting the service quality and customer satisfaction in telecom industry of Pakistan. International Journal of Management, Accounting and Economics, 3(9), 509-520.

2. Armstrong, R.W., Mok, C., Go, F.M., \& Chan, A. (1997). The importance of cross-cultural expectations in the measurement of service quality perceptions in the hotel industry. International Journal of Hospitality Management, 16(2), 181-190.

3. Beirão, G., \& Cabral, J.S. (2007). Understanding attitudes towards public transport and private car: A qualitative study. Transport Policy, 14(6), 478-489.

4. Bentler, P.M. (1990). Comparative fit indexes in structural models. Psychol Bull, 107, 238-246.

5. Bharadwaj, Y.P., \& Singh, M. (2020). The Effect of Service Quality on Commuters' Satisfaction towards the Adoption of Metro Services: A Case Study of Delhi Metro Rail Corporation. International Journal on Emerging Technologies, 11(2), 237-244.

6. Botzoris, G., Galanis, A., Profillidis, V., \& Eliou, N. (2015). Commuters' perspective on urban public transport system service quality. WSEAS Trans. Environ. Dev, 11, 182-192.

7. Brown, T.J., Gilbert A. Churchill, Jr., \& Peter, J.P. (1993). Improving the Measurement of Service Quality. Journal of Retailing, 69(1), 127-139.

8. Byrne, B.M. (2001). Structural equation modeling with AMOS: Basic Concepts, Applications, and Programming. Mahwah, NJ: Lawrence Erlbaum.

9. Cavana, R., Delahaye, B., \& Sekaran, U. (2000). Applied Business Research: Qualitative and Quantitative Methods. USA: John Wiley \& Sons Inc.

10. Chopra, T.J.S. (1994). Delhi Transport Corporation: Performance and Prospects. In P.J.

11. Gandhi and G.J. Gunaseelan (eds.), Indian Transport System, Mittal Publications, New Delhi.

12. Churchill, Gilbert A., Jr., \& Carol, S. (1982). An Investigation into the Determinants of Customer Satisfaction. Journal of Marketing Research, 19(11), 491-504.

13. Corry, A. (1997). Operators must focus on service delivery. Passenger Rail Management, 24(1), 7-31.

14. Cronbach, L.J. (1951). Coefficient alpha and the internal structure of tests. Psychometrica, 6(3), $297-$ 334.

15. Cronin, J.J., Brady, M.K., \& Hult, G.T. (2000). Assessing the Effects of Quality, Value and Customer Satisfaction on Consumer Behavioural Intentions in Service Environments. Journal of Retailing, 76(2), 193-218.

16. Dean, A. (1999). The applicability of SERVQUAL in different health-care environments. Health Marketing Quarterly, 16(3), 1-21.

17. Delhi Metro Rail Corporation. (2018). Annual Report 2017-18. Delhi Metro Rail Corporation Limited, New Delhi.

18. Ettema, D., Friman, M., Gärling, T., Olsson, L.E., \& Fujii, S. (2012). How in-vehicle activities affect work commuters' satisfaction with public transport. Journal of Transport Geography, 24, 215-222.

19. Gao, Y., Rasouli, S., Timmermans, H., \& Wang, Y. (2017). Understanding the relationship between travel satisfaction and subjective well-being considering the role of personality traits: A structural equation model. Transportation research part F: traffic psychology and behaviour, 49, 110-123.

20. Gallifa, J., \& Batallé, P. (2010). Student perceptions of service quality in a multi-campus higher education system in Spain. Quality Assurance in Education, 18(2), 156-170.

21. Gray, B., \& Boshoff, C. (2004). The relationships between service quality, customer satisfaction and buying intentions in the private hospital industry. South African Journal of Business Management, 35(4), 27-37.

22. Grönroos, C. (2000). Service Management and Marketing- A Customer Relationship Management Approach, Wiley.

23. Hair, J.F., Black, W.C., Babin, B.J., \& Anderson, R.E. (2010). Multivariate Data Analysis. Pearson, New York.

24. Hill, N., \& Jim, A. (2000). Handbook of Customer Satisfaction and Loyalty Measurement. Gower Publishing, Ltd.

25. Hooper, D., Coughlan, J., \& Mullen, M.R. (2008). Structural Equation Modelling: Guidelines for Determining Model Fit. The Electronic Journal of Business Research Methods, 6, 53-60.

26. Hossain, M.J. (2012). Impact of service quality on customer satisfaction: A case of tourism industry in Bangladesh. International Journal of Research in Finance \& Marketing, 2(2), 1-25.

27. Hu, L.T., \& Bentler, P.M. (1998). Fit indices in covariance structure modeling: Sensitivity to under parameterized model misspecification. Psychological Methods, 3(4), 424-453.

28. Karim, R., \& Chowdhury, T. (2014). Customer satisfaction on service quality in private commercial banking sector in Bangladesh. British Journal of Marketing Studies, 2(2), 1-11.

29. Kerlinger, F.N. (1986). Foundations of Behavioral Research. Holt Rinehart \& Winston. 
30. Khan, M.M., \& Fasih, M. (2014). Impact of service quality on customer satisfaction and customer loyalty: Evidence from banking sector. Pakistan Journal of Commerce and Social Sciences (PJCSS), $8(2), 331-354$.

31. Knutson, B., Stevens, P., Wullaert, C., Patton, M., \& Yokoyama, F. (1990). LODGSERV: A service quality index for the lodging industry. Hospitality Research Journal, 14(2), 277-284.

32. Krejcie, R.V., \& Morgan, D.W. (1970). Determining sample size for research activities. Educational and Psychological Measurement, 30(3), 607-610.

33. Nandan, S. (2010). Determinants of customer satisfaction on service quality: A study of railway platforms in India. Journal of Public Transportation, 13(1), 21-34.

34. Ojo, O. (2010). The relationship between service quality and customer satisfaction in the telecommunication industry: Evidence from Nigeria.BRAND-Broad Research in Accounting, Negotiation, and Distribution, 1(1), 88-100.

35. Parasuraman, A., Zeithaml, V.A., \& Berry, L.L. (1988). Servqual: A multiple-item scale for measuring customer perceptions of service quality. Journal of Retailing, 64(1), 12-40.

36. Santouridis, I., \& Trivellas, P. (2010). Investigating the impact of service quality and customer satisfaction on customer loyalty in mobile telephony in Greece. The TQM Journal, 22(3), 330-343.

37. Sekaran, U. (2003). Research Methods for Business: a skill-building approach. Journal of Education for Business, 68(5), 316-317.

38. Wang, K.Y., Hsu, L.C., \& Chih, W.H. (2014). Retaining customers after service failure recoveries: a contingency model. Managing Service Quality, 24(4), 318-338.

39. Wu, S., Bai, Q., \& Sengvong, S. (2018). Green Commute: an influence-aware persuasive recommendation approach for public-friendly commute options. Journal of Systems Science and Systems Engineering, 27(2), 250-264.

40. Yang, M., Zhao, J., Wang, W., Liu, Z., \& Li, Z. (2015). Metro commuters' satisfaction in multi-type access and egress transferring groups. Transportation Research Part D: Transport and Environment, 34, 179-194.

41. Zeithaml, V.A., Parasuraman, A., \& Berry, L.L. (1985). Problems and strategies in services marketing. Journal of Marketing, 49(2), 33-46. 